\title{
Effect of energy and protein supplementation on growth and nutrient requirement estimation in crossbred bull calf
}

\author{
MN Akhter ${ }^{1}$, MR Islam², MR Habib ${ }^{3}$, MH Rashid ${ }^{3}$ and ZH Khandaker ${ }^{1 *}$ \\ Affiliation: ${ }^{1}$ Department of Animal Nutrition, Bangladesh Agricultural University, Mymensingh; ${ }^{2}$ Department of \\ Animal Breeding and Genetics, Bangladesh Agricultural University, Mymensingh; ${ }^{2}$ Department of \\ Dairy Science, Bangladesh Agricultural University, Mymensingh-2202, Bangladesh
}

\begin{abstract}
This study was carried out to investigate the effects of supplying different levels of energy and protein on the growth performance and nutrient requirements estimation in crossbred bull calves. Feeding trial was conducted for 60 days with 12 numbers of crossbred bull calves. The animals were divided into four groups i.e. $T_{0}, T_{1}, T_{2}$ and $T_{3}$. Four levels of metabolizable energy (ME) and digestible crude protein (DCP) were supplied respectively in four dietary groups, $T_{0}=17.4 \mathrm{MJ} / \mathrm{d}$ and $85 \mathrm{~g} / \mathrm{d}$ as maintenance ration, $\mathrm{T}_{1}=19.22 \mathrm{MJ} / \mathrm{d}$ and $188 \mathrm{~g} / \mathrm{d}$ for $200 \mathrm{~g} / \mathrm{d}$ targeted BWG, $T_{2}=21.29 \mathrm{MJ} / \mathrm{d}$ and $243 \mathrm{~g} / \mathrm{d}$ for $400 \mathrm{~g} / \mathrm{d}$ targeted BWG, $T_{3}=23.37 \mathrm{MJ} / \mathrm{d}$ and $255 \mathrm{~g} / \mathrm{d}$ for $600 \mathrm{~g} / \mathrm{d}$ targeted BWG. A positively correlation of BWG with uptake of nutrients (energy and protein) and feed conversion efficiency of different dietary groups was observed. Results revealed that the average daily body weight gain (BWG) in $T_{1}(200 \mathrm{~g} / \mathrm{d})$ fulfills against the targeted BWG $200 \mathrm{~g} / \mathrm{d}, \mathrm{T}_{2}$ maintaining BWG $327 \mathrm{~g} / \mathrm{d}$ against the targeted BWG $400 \mathrm{~g} / \mathrm{d}$ and $\mathrm{T}_{3}$ maintaining BWG $422 \mathrm{~g} / \mathrm{d}$ against the targeted BWG $600 \mathrm{~g} / \mathrm{d}$. Considering the growth response of crossbred bull calves it is evident that $T_{1}$ is better than other dietary groups. Again, estimated ME requirement for maintenance was $16.14 \mathrm{MJ} / \mathrm{d}$ and for each $\mathrm{kg}$ BWG/d requires ME was $14.69 \mathrm{MJ}$ for 100 $\mathrm{kg}$ body weight of crossbred bull calves. The maintenance requirement of DCP was $60.65 \mathrm{~g} / \mathrm{d}$ and for each $\mathrm{kg} \mathrm{BWG/d}$ requires DCP was $0.56 \mathrm{~g}$ for $100 \mathrm{~kg}$ body weight of crossbred bull calves.
\end{abstract}

Key words: energy, protein, body weight gain, feed conversion efficiency, nutrient requirement.

Bangladesh Animal Husbandry Association. All rights reserved.

Bang. J. Anim. Sci. 2017. 46 (3): 179-187

\section{Introduction}

The success of any bull calves rearing system depends on either feedlot or pastures and adequacy of the diet to the nutritional needs of bull calves. The nutritional plan shall be well designed as because about $70 \%$ of the cost of production related to feed cost. Bull calves rearing are a systematic way of management and mostly reared as a component of traditional cropbased mixed farming system in Asian countries. Some people use both conventional and unconventional feed ingredients for fattening yearling bull calves (Banglapedia, 2014). Green grass, rice straw, rice polish, wheat bran, rice bran, rice gruel, urea molasses block and urea molasses straw etc. are usually fed to the bull calves. Again, farmers rear indigenous bull calves through tethering as well as traditional system of grazing without any supplementation. Consequently, this system of production retarded growth performance of animals, ultimately severe economic losses occur. Also, crossbred bull calves cannot show their production potentials due to harsh environmental conditions, non-availability of green forage, unskilled management and lack of knowledge about health care.
In fact, crossbred bull calves have a higher nutritional requirement and better adaptability than pure breeds in BD (Alam et al., 2001). There is no systematic and appropriate developed feeding strategy for crossbred cattle in our country. Most of the farmers and cattle owner do not afford proper nourishment to their calves. Good nutrition is essential for all of the systems of bull calves to function and work together properly. Nutrient requirements of bull calves changes based on age, sex, breed, level of activity, pest load and environment. The basic nutrient requirements of the herd are very essential to make informed and effective nutrition related decisions. Also, nutrient requirement is pre-requisite to developed feeding standard of bull calves. Nutrition plays a major role in attaining the proper weight at proper time (Martson et al., 1995). Bull calves consume protein in their diets and then utilize the amino acids for synthesis of muscle, blood proteins and other body components. Protein requirement depends upon the body weight and rate of gain. As a general rule, the protein requirement for maintenance is relatively low but the requirement for gain needed relatively high. The opposite is true for energy requirement is high for

*Corresponding author: zhkhandakar@yahool.com 
Growth and nutrient requirements of bull calf

maintenance and relatively low for additional gain. Dietary protein is essential for growth and development. However, protein receives the most attention due to it's most expensive component of the diet for the young calf (Davis and Drackley, 1998). Energy and protein are most critical nutrients which influence bull calves productive performance under tropical or subtropical conditions (Shahzadet al., 2010). If the supply of protein is adequate then dietary energy is major limiting factor for ruminant growth and protein supplement alone with low energy diet has limited effect on growth rate (Mtenga and Madsen, 1992). The trend of increasing energy intake bears a positive propensity of increasing body weight gain in bull calves. The daily total ME requirements for crossbred bull is $42.2 \mathrm{MJ}$; of which $23.9 \mathrm{MJ}$ and $18.3 \mathrm{MJ}$ are required for maintenance and production (ADAS, 1991). Regression analysis of feeding trial data provides estimation of nutrient requirements of producing bull calves kept under normal farm feeding condition and hence such approach has been widely used (Paul et al., 2004).

Several studies conducted with Holstein $\times$ Zebu crossbreds showed that this type of bull calves has the potential for meat production (Costa et al., 2012). Because of the wide variation in conditions (bull calves species, breed and age, food availability, quality and peculiarities inherent to the various geographic regions and seasons) in Bangladesh compared with other countries and also within the country a study of the nutritional requirements of cattle under different raising conditions is necessary. The livestock production industry in Bangladesh has been using the feeding standards and management techniques prescribed by the scientific organizations of western countries which are based on data adapted to their existing climate and condition. So, feeding standards particularly nutrient requirements should be developed through research by using crossbred cattle is of high importance. However, reports on the nutrient requirements of crossbred bull calves are scanty and limited information is available particularly on the contribution of dietary energy and protein to the growth performance of these bull calves under Bangladesh condition. Hence, this research work was undertaken to know the effects of supplying different levels of energy and protein on growth performance, nutrient intake and digestibility in crossbred bull calves. Also, protein and energy requirements estimated for maintenance and growth of crossbred bull calves.

\section{Materials and Methods}

\section{Site and duration of the experiment}

The entire experiment encompasses with two sections like bull calves feeding trial and laboratory analysis. The bull calves feeding trial was conducted at Bangladesh Agricultural University Dairy Farm (BAUDF), Mymensingh, Bangladesh. The laboratory analysis for chemical composition of feed and faeces were done at Animal Nutrition Laboratory of Bangladesh Agricultural University, Bangladesh. This experiment was carried out for a period of 60 days from June 1 to July 29, 2015.

\section{Animals and diets}

Twelve healthy male crossbred (Indigenous $\times$ $50 \%$ Holstein-Friesian) bull calves were selected for this study and grouped into three blocks such as $A, B$, and $C$ based on their body weight. The four dietary treatments like $T_{0}$ (maintenance ration), $T_{1}, T_{2}$ and $T_{3}$ were randomly distributed in each block. Each group consisted of 3 bull calves. The bull calves were kept individually in a well ventilated "face out stanchion barn" and allow sufficient space to keep them comfortable. The bull calves were dewormed previously by broad spectrum anthelmintic (A-Mectin plus vet injection, The ACME Laboratories Limited, Veterinary Division, Dhaka, Bangladesh). The study was conducted using roughages: rice straw (Oryza sativa), green grass [Para grass (Brachiariamutica)], Germangrass [(Echinochloa crus-galli) $=50: 50]$ and concentrate. The maintenance diet $\left(T_{0}\right)$ consisted rice straw and green grass. The other diets like $T_{1}$ to $T_{3}$ contained various rates of concentrates. Four levels of dietary metabolizable energy (ME) and digestible crude protein (DCP) were supplied respectively in $T_{0}: 17.4 \mathrm{MJ} / \mathrm{d}$ and $85 \mathrm{~g} / \mathrm{d}$ as maintenance ration; $\mathrm{T}_{1}: 19.22 \mathrm{MJ} / \mathrm{d}$ and $188 \mathrm{~g} / \mathrm{d}$ for $200 \mathrm{~g} / \mathrm{d}$ targeted BWG; $\mathrm{T}_{2}: 21.29 \mathrm{MJ} / \mathrm{d}$ and $243 \mathrm{~g} / \mathrm{d}$ for $400 \mathrm{~g} / \mathrm{d}$ targeted BWG and $T_{3}: 23.37$ $\mathrm{MJ} / \mathrm{d}$ and $255 \mathrm{~g} / \mathrm{d}$ for $600 \mathrm{~g} / \mathrm{d}$ targeted BWG. The requirements of $\mathrm{ME}$ and $\mathrm{DCP}$ were calculated according to MAFF (1984) and AFRC (1993). Based on the intake during the pre-trial period, $3 \%$ (of the body weight) DM was offered to each bull calves. Roughage and concentrate mixture were fed separately two times daily i.e. 7.00 AM and 4.00 PM. Ingredient composition and chemical composition of four diets are shown in Table 1. 
Akhter et al. (2017) Bang. J. Anim. Sci. 46 (3):179-187

Table 1. Ingredient and chemical composition of different dietary groups

\begin{tabular}{lcccc}
\hline & \multicolumn{3}{c}{ Dietary treatment group } \\
\cline { 2 - 4 } & $\mathbf{T}_{\mathbf{0}}$ & $\mathbf{T}_{\mathbf{1}}$ & $\mathbf{T}_{\mathbf{2}}$ & $\mathbf{T}_{\mathbf{3}}$ \\
\hline Ingredient (g/100g DM) & & & \\
Rice straw & 39.68 & 34.49 & 21.27 & 16.45 \\
Green grass & 55.56 & 47.90 & 35.46 & 29.62 \\
Crust maize & - & - & 17.75 & 29.62 \\
Wheat bran & - & 1.92 & 3.54 & 3.62 \\
Rice polish & - & 1.92 & 3.54 & 3.62 \\
Mustard oil cake & - & 9.19 & 14.18 & 13.15 \\
Salt & 4.76 & 4.58 & 4.26 & 3.92 \\
Chemical composition (\%) & & & \\
Crude protein & 6.53 & 8.97 & 11.41 & 11.60 \\
Crude fiber & 31.51 & 26.31 & 20.73 & 19.46 \\
Ether extract & 2.65 & 3.71 & 4.38 & 4.83 \\
Nitrogen-free-extract & 47.17 & 47.20 & 52.62 & 55.41 \\
Ash & 12.14 & 13.81 & 10.67 & 8.89 \\
ME (MJ/kg DM) & 6.84 & 7.48 & 8.36 & 8.51 \\
Digestible crude protein (\%) & 32.84 & 59.23 & 71.90 & 79.57 \\
\hline
\end{tabular}

\section{Measurement of dry matter intake and growth performance}

Daily DM intake $(\mathrm{kg})$ was estimated from the feed supplied and orts. Body weight $(\mathrm{kg})$, height at withers $(\mathrm{cm})$, body length $(\mathrm{cm})$, and heart girth $(\mathrm{cm})$ of heifers were measured by using a weighing balance (Zhunsheng scale, Motor carbrand, China), measuring wooden scale and measuring tape, respectively.

\section{Digestibility trial}

A conventional digestion trial was conducted for a period of 7 days at the end of experimental period to find out the digestibility of proximate components of diets. Amount of feed supply, refusal amount of feed and voided faeces were recorded daily. Then representative parts of feed and faeces samples were subjected to chemical analysis. Digestibility was calculated using the following formula:

$\%$ Digestibi.ity $=\frac{\text { intake }- \text { outgo }}{\text { tnugke }} \times 100$

Chemical composition was determined according to the method described in AOAC (2000) and DCP and ME were determined by method of Satter and Roffler (1976).

\section{Statistical analysis}

Data was analyzed using SAS (2007) software version 6.1.3 statistical computer program in Randomized Completely Block Design (RCBD) to compute Analysis of variance (ANOVA). Finally, requirement of protein and energy for maintenance and growth were calculated by means of regression method.

\section{Results and Discussion}

\section{Dry matter and nutrient intake}

Effects of supplying different levels of energy and protein on DM and nutrient intake in crossbred bull calves are shown in Table 2. The lowest DMI was observed in $T_{0}$ and no significant $(p>0.05)$ difference existed among the dietary groups which indicated that different levels of dietary energy and protein had no effect on the total DMI in bull calves. The total DMI were found higher in $\mathrm{T}_{3}$ than the other diets when expressed as $\mathrm{g} / \mathrm{kg}$ $\mathrm{W}^{0.75}, \mathrm{~kg} / 100 \mathrm{~kg} \quad \mathrm{BW}$ then non-significant difference existed among the different groups. These results are in agreement with the findings of Barua et al. (2008) who reported that higher protein level influences DMI of animals through increasing protein levels up to optimum levels $(30 \%)$ for maximum gains. But Mohan and Ranjhan (1985) observed that increasing protein levels didn't affect the DMI. 
Growth and nutrient requirements of bull calf

Table 2. Nutrient intake parameters from bull calves fed different diets

\begin{tabular}{|c|c|c|c|c|c|c|}
\hline Parameter & $T_{0}$ & $\mathbf{T}_{\mathbf{1}}$ & $\mathbf{T}_{2}$ & $\mathbf{T}_{3}$ & p-value & $\begin{array}{c}\text { Level } \\
\text { of } \\
\text { Sig. }\end{array}$ \\
\hline Total DMI (kg/d) & $2.59^{b} \pm 0.20$ & $3.18^{\mathrm{a}} \pm 0.11$ & $3.21^{\mathrm{a}} \pm 0.11$ & $3.38^{\mathrm{a}} \pm 0.19$ & 0.193 & NS \\
\hline $\begin{array}{l}\text { DMI } \\
\text { (kg/100kgBW) }\end{array}$ & $2.64^{\mathrm{a}} \pm 0.24$ & $3.03^{\mathrm{a}} \pm 0.13$ & $2.98^{a} \pm 0.14$ & $3.04^{a} \pm 0.24$ & 0.372 & NS \\
\hline DMI $\left(\mathrm{gkg}^{-1} \mathrm{~W}^{0.75}\right)$ & $83.69^{\mathrm{a}} \pm 7.86$ & $95.82^{\mathrm{a}} \pm 4.37$ & $94.34^{\mathrm{a}} \pm 4.44$ & $96.34^{\mathrm{a}} \pm 7.73$ & 0.372 & NS \\
\hline CPI $(g / d)$ & $179.66^{\mathrm{C}} \pm 6.77$ & $286.66^{b} \pm 3.76$ & $381.33^{\mathrm{a}} \pm 3.83$ & $385.66^{\mathrm{a}} \pm 6.66$ & 0.000 & $* *$ \\
\hline $\begin{array}{l}\text { CPI }(\mathrm{kg} / 100 \mathrm{~kg} \\
\text { BW) }\end{array}$ & $\begin{array}{c}184.70^{\complement} \pm 21.1 \\
2\end{array}$ & $273.13^{\mathrm{b}} \pm 11.73$ & $355.24^{a} \pm 11.93$ & $347.29^{\mathrm{a}} \pm 20.78$ & 0.007 & $* *$ \\
\hline CPI $\left(\mathrm{g} \mathrm{kg}^{-1} \mathrm{~W}^{0.75}\right)$ & $5.83^{c} \pm 0.79$ & $8.33^{b} \pm 0.44$ & $11.23^{\mathrm{a}} \pm 0.44$ & $10.98^{\mathrm{a}} \pm 0.77$ & 0.011 & $*$ \\
\hline DCPI $(g / d)$ & $85.06^{c} \pm 13.94$ & $188.36^{b} \pm 7.74$ & $243.05^{\mathrm{a}} \pm 13.71$ & $255.44^{\mathrm{a}} \pm 7.88$ & 0.001 & $* *$ \\
\hline $\begin{array}{l}\text { DCPI } \\
(\mathrm{kg} / 100 \mathrm{kgBW})\end{array}$ & $89.42^{c} \pm 20.51$ & $180.56^{\mathrm{b}} \pm 11.40$ & $219.43^{a} \pm 20.18$ & $238.92^{\mathrm{a}} \pm 11.59$ & 0.009 & $* *$ \\
\hline DCPI $\left(\mathrm{g} \mathrm{kg}^{-1} \mathrm{~W}^{0.75}\right)$ & $2.82^{c} \pm 0.65$ & $5.70^{b} \pm 0.36$ & $6.93^{a} \pm 0.63$ & $7.55^{\mathrm{a}} \pm 0.37$ & 0.009 & $* *$ \\
\hline MEI $(M J / d)$ & $17.40^{d} \pm 0.05$ & $19.22^{\mathrm{c}} \pm 0.20$ & $21.29^{b} \pm 0.07$ & $23.37^{\mathrm{a}} \pm 0.10$ & 0.000 & $* *$ \\
\hline
\end{tabular}

DMI, dry matter intake; CPI, crude protein intake; DCPI, digestible crude protein intake; MEI, metabolizable energy intake. $T_{0}=17.40 \mathrm{MJ} / \mathrm{d}$ and $85 \mathrm{~g} / \mathrm{d}(\mathrm{DCP})$ for maintenance ration, $\mathrm{T}_{1}=19.22 \mathrm{MJ} / \mathrm{d}$ and $188 \mathrm{~g} / \mathrm{d}$ (DCP) for $200 \mathrm{~g} / \mathrm{d}$ targeted BWG, $T_{2}=21.29 \mathrm{MJ} / \mathrm{d}$ and $243 \mathrm{~g} / \mathrm{d}$ (DCP) and $255 \mathrm{~g} / \mathrm{d}$ (DCP) for $400 \mathrm{~g} / \mathrm{d}$ targeted BWG, $T_{3}=23.37 \mathrm{MJ} / \mathrm{d}$ for $600 \mathrm{~g} / \mathrm{d}$ targeted). ${ }^{\text {abcd }}$ Mean values in a row with different superscripts differed significantly. ** Significant at $\mathrm{p}<0.01, *$ significant at $\mathrm{p}<0.05$ and NS indicates non-significant.

Table 2 revealed that crude protein intake (CPI) and digestible crude protein intake (DCPI) differed significantly $(p<0.01)$ among the groups of bull calves through receiving different energy and protein in diet. The results indicated that CPI and DCPI of were found higher in $\mathrm{T}_{3}$ followed by other diets. Prakash et al. (2006) who reported that high protein diet influenced remarkably to increase CP and DCP intake which might be due to deposition of protein in bull calves body. Increased CPI with increasing CP levels in supplements in the present study corresponds well with other findings (Gilbery et al., 2006). Average daily ME intake was significantly $(p<0.01)$ higher in $T_{3}, T_{2}$ and $T_{1}$ compared to $T_{0}$ which is consistent with the findings of Yasmin (2006). The present findings are in a good agreement with Natthamon (2012) who reported that the dry matter intake was increased significantly $(p<0.05)$ with increasing MEI.

\section{Apparent digestibility and nutritive value of diets}

The effect of feeding different levels of energy and protein on apparent digestibility and nutritive value of diets is shown in Table 3. The DM digestibility was significantly $(p<0.05)$ higher in all diet except $T_{0}$. From the Table, it is evident that the digestibility of DM increased significantly $(p<0.05)$ up to certain level with the increased level of protein content of the diet. Grigor'ev and Gaganov (1991) found the highest digestibility of nutrients in case of supplying high energy level in diet and vice-versa.

The digestibility of $\mathrm{CP}, \mathrm{CF}$ and NFE increased significantly $(p<0.05)$ with increasing level of energy and protein in diets. The digestibility of $\mathrm{CP}$ and CF were significantly higher $(p<0.05)$ in diet $\mathrm{T}_{3}$ and Chowdhury (1999) stated that increasing levels of mustard oil cake in diet CP digestibility increased. On the other hand, digestibility of $\mathrm{EE}$ was not significantly differed among the dietary treatments. The digestibility of $\mathrm{CP}, \mathrm{CF}$ and NFE were significantly $(p<0.05)$ higher in high protein diet compared with low protein diet. Reddy and Reddy (1988) also stated that supplementation (energy and protein) of diet increased the digestibility of DM, OM, CP, EE and NFE in case of crossbred calves. 
Akhter et al. (2017) Bang. J. Anim. Sci. 46 (3):179-187

Table 3. Apparent digestibility and nutritive value of different experimental diets

\begin{tabular}{|c|c|c|c|c|c|c|}
\hline Parameter & $\mathbf{T}_{\mathbf{0}}$ & $\mathbf{T}_{\mathbf{1}}$ & $\mathbf{T}_{2}$ & $\mathbf{T}_{3}$ & p-value & $\begin{array}{c}\text { Level } \\
\text { of } \\
\text { Sig. }\end{array}$ \\
\hline \multicolumn{7}{|c|}{ Apparent digestibility (\%) } \\
\hline Dry matter & $56.73^{b} \pm 4.57$ & $62.85^{\mathrm{a}} \pm 2.54$ & $63.42^{a} \pm 2.58$ & $68.95^{\mathrm{a}} \pm 4.49$ & 0.014 & $*$ \\
\hline Crude protein & $50.66^{c} \pm 7.71$ & $65.94^{b} \pm 4.28$ & $68.63^{a} \pm 4.36$ & $71.25^{\mathrm{a}} \pm 7.59$ & 0.031 & * \\
\hline Crude fiber & $63.49^{b} \pm 7.96$ & $63.03^{\mathrm{b}} \pm 4.42$ & $60.21^{\mathrm{b}} \pm 4.50$ & $71.70^{a} \pm 7.83$ & 0.043 & * \\
\hline Ether extract & $87.27^{\mathrm{a}} \pm 4.52$ & $89.88^{a} \pm 2.51$ & $88.10^{a} \pm 2.55$ & $86.28^{a} \pm 4.45$ & 0.053 & NS \\
\hline Nitrogen-free-extract & $42.39^{d} \pm 1.82$ & $51.11^{\mathrm{c}} \pm 3.13$ & $56.53^{\mathrm{a}} \pm 3.82$ & $56.28^{\mathrm{b}} \pm 3.20$ & 0.040 & * \\
\hline \multicolumn{7}{|l|}{ Nutritive value (\%) } \\
\hline DCP & $7.50^{\mathrm{C}} \pm 1.23$ & $8.91^{b} \pm 0.68$ & $7.95^{\mathrm{a}} \pm 0.69$ & $8.50^{\mathrm{a}} \pm 1.21$ & 0.0073 & $* *$ \\
\hline DCF & $10.00^{\mathrm{a}} \pm 1.74$ & $12.57^{b} \pm 0.97$ & $11.06^{\mathrm{c}} \pm 0.98$ & $3.94^{d} \pm 1.71$ & 0.011 & * \\
\hline DEE & $2.30^{\mathrm{b}} \pm 2.20$ & $3.33^{\mathrm{b}} \pm 1.22$ & $3.85^{\mathrm{b}} \pm 1.24$ & $30.71^{a} \pm 2.16$ & 0.002 & $* *$ \\
\hline DNFE & $19.69^{\mathrm{c}} \pm 4.21$ & $23.25^{\mathrm{b}} \pm 2.34$ & $29.47^{b} \pm 2.38$ & $54.77^{\mathrm{a}} \pm 4.14$ & 0.006 & $* *$ \\
\hline TDN & $50.18^{\mathrm{b}} \pm 5.78$ & $53.24^{\mathrm{a}} \pm 3.21$ & $57.13^{\mathrm{a}} \pm 3.27$ & $59.33^{\mathrm{a}} \pm 5.69$ & 0.007 & $* *$ \\
\hline $\begin{array}{l}\text { Estimated ME } \\
(\mathrm{MJ} / \mathrm{kg} \mathrm{DM})\end{array}$ & $6.84^{d} \pm 0.17$ & $7.48^{\mathrm{c}} \pm 0.32$ & $8.36^{\mathrm{b}} \pm 0.50$ & $8.51^{a} \pm 0.42$ & 0.031 & * \\
\hline
\end{tabular}

$\mathrm{DCP}$, digestible crude protein; DCF, digestible crude fiber; DEE, digestible ether extract; DNFE, digestible nitrogen-free-extract; TDN, total digestible nutrients, ME, metabolizable energy. $\mathrm{T}_{0}: 17.40 \mathrm{MJ} / \mathrm{d}$ and 85 $\mathrm{g} / \mathrm{d}(\mathrm{DCP})$ for maintenance ration; $\mathrm{T}_{1}: 19.22 \mathrm{MJ} / \mathrm{d}$ and $188 \mathrm{~g} / \mathrm{d}$ (DCP) for $200 \mathrm{~g} / \mathrm{d}$ targeted $\mathrm{BWG} ; \mathrm{T}_{2}$ : $21.29 \mathrm{MJ} / \mathrm{d}$ and $243 \mathrm{~g} / \mathrm{d}$ (DCP) and $255 \mathrm{~g} / \mathrm{d}$ (DCP) for $400 \mathrm{~g} / \mathrm{d}$ targeted BWG and $\mathrm{T}_{3}: 23.37 \mathrm{MJ} / \mathrm{d}$ for 600 $\mathrm{g} / \mathrm{d}$ targeted). ${ }^{\text {abcd }}$ Mean values in a row with different superscripts differed significantly. ** Significant at $\mathrm{p}<0.01, *$ significant at $\mathrm{p}<0.05$ and NS indicates non-significant.

There was significant difference $(p<0.01)$ among the different dietary groups in terms of DCP, DEE, DNFE and TDN. DCF also significantly $(p<0.05)$ differed in among the dietary groups. Estimated ME contents of different diets showed significant $(p<0.05)$ variations between treatments being the highest in $T_{3}$ whereas the lowest in $T_{0}$. It is clear from the result that dietary level of energy and protein affects the nutritive value of diet. The present findings are in agreement with Sugimoto et al. (2004) who reported that increased TDN intake resulted in increased average daily gain.

\section{Growth performance of crossbred bull calves}

Growth measurement parameters of crossbred bull calves are shown in Table 4 and the highest body weight gain was found in $T_{3}$ diet than others. The results showed that there was significant difference $(p<0.01)$ in body weight gain which due to increasing dietary energy and protein levels. This statement is in agreement with the findings of Limea et al. (2009) who reported that growth rate of ruminant increased with increasing level of energy and protein in diet. Similarly, Habib et al. (2018) described that increase energy and DCP level in diet positively influences animal growth performances. 
Table 4. Growth performance and feed conversion efficiency of crossbred bull calves fed different diets

\begin{tabular}{|c|c|c|c|c|c|c|}
\hline \multirow{2}{*}{ Parameter } & \multicolumn{4}{|c|}{ Dietary group } & \multirow[b]{2}{*}{$\begin{array}{c}\text { p- } \\
\text { value }\end{array}$} & \multirow[b]{2}{*}{$\begin{array}{l}\text { Level } \\
\text { of Sig. }\end{array}$} \\
\hline & $\mathbf{T}_{\mathbf{0}}$ & $\mathbf{T}_{1}$ & $\mathbf{T}_{2}$ & $\mathbf{T}_{3}$ & & \\
\hline $\begin{array}{l}\text { Initial body } \\
\text { weight (kg) }\end{array}$ & $98.00^{a} \pm 3.65$ & $101.00^{\mathrm{a}} \pm 4.43$ & $101.33^{\mathrm{a}} \pm 4.50$ & $99.66^{\mathrm{a}} \pm 4.32$ & 0.081 & NS \\
\hline $\begin{array}{l}\text { Final body } \\
\text { weight (kg) }\end{array}$ & $100.66^{d} \pm 2.81$ & $113.00^{c} \pm 3.85$ & $121.00^{\mathrm{b}} \pm 2.21$ & $125.00^{\mathrm{a}} \pm 3.55$ & 0.049 & $*$ \\
\hline Total BWG (kg) & $2.66^{d} \pm 0.2$ & $12.00^{c} \pm 0.5$ & $19.67^{b} \pm 1.12$ & $25.33^{\mathrm{a}} \pm 1.68$ & 0.007 & $* *$ \\
\hline BWG $(\mathrm{kg} / \mathrm{d})$ & $0.043^{d} \pm 0.02$ & $0.2^{c} \pm 0.01$ & $0.327^{\mathbf{b}} \pm 0.01$ & $0.422^{\mathrm{a}} \pm 0.02$ & 0.006 & $* *$ \\
\hline $\begin{array}{l}\text { Total WHG } \\
(\mathrm{cm} / 15 \mathrm{~d})\end{array}$ & $4.96 \pm 3.48$ & $5.41 \pm 1.59$ & $5.29 \pm 2.88$ & $4.65 \pm 2.25$ & 0.773 & NS \\
\hline WHG /day $(\mathrm{cm})$ & $0.06 \pm 0.01$ & $0.04 \pm 0.04$ & $0.09 \pm 0.04$ & $0.07 \pm 0.03$ & 0.045 & NS \\
\hline Total BLG (cm) & $7.41 \pm 6.94$ & $6.99 \pm 3.17$ & $8.04 \pm 5.75$ & $11.85 \pm 4.50$ & 0.898 & NS \\
\hline BLG /day (cm) & $0.12 \pm 0.01$ & $0.11 \pm 0.05$ & $0.13 \pm 0.09$ & $0.19 \pm 0.07$ & 0.895 & NS \\
\hline Total HGG (cm) & $4.0^{b} \pm 3.41$ & $3.0^{\mathrm{b}} \pm 1.56$ & $9.0^{\mathrm{a}} \pm 2.82$ & $11.0^{\mathrm{a}} \pm 2.21$ & 0.037 & $*$ \\
\hline HGG/day (cm) & $0.06^{b} \pm 0.03$ & $0.05^{b} \pm 0.02$ & $0.15^{\mathrm{a}} \pm 0.04$ & $0.18^{\mathrm{a}} \pm 0.03$ & 0.035 & $*$ \\
\hline FCE (DMI/BWG) & $58.53^{a} \pm 11.79$ & $16.41^{b} \pm 9.89$ & $10.00^{b} \pm 10.06$ & $12.13^{\mathbf{b}} \pm 17.50$ & 0.021 & $*$ \\
\hline PCE (CPI/BWG) & $4.39^{\mathrm{a}} \pm 1.50$ & $1.47^{b} \pm 0.08$ & $1.18^{\mathrm{c}} \pm 0.07$ & $0.92^{d} \pm 0.04$ & 0.007 & $* *$ \\
\hline $\begin{array}{l}\text { Energetic } \\
\text { efficiency } \\
\text { (MJMEI/kg } \\
\text { BWG) }\end{array}$ & $404.65^{a} \pm 6.65$ & $98.06^{\mathrm{b}} \pm 4.84$ & $65.91^{d} \pm 2.56$ & $70.17^{c} \pm 5.64$ & 0.032 & $*$ \\
\hline
\end{tabular}

BWG, body weight gain; WHG, wither height gain; BLG, body length gain; HGG, heart girth gain; FCE, feed conversion efficiency; PCE, protein conversion efficiency. $\mathrm{T}_{0}=17.40 \mathrm{MJ} / \mathrm{d}$ and $85 \mathrm{~g} / \mathrm{d}$ (DCP) for maintenance ration, $T_{1}=19.22 \mathrm{MJ} / \mathrm{d}$ and $188 \mathrm{~g} / \mathrm{d}(\mathrm{DCP})$ for $200 \mathrm{~g} / \mathrm{d}$ targeted $\mathrm{BWG}, \mathrm{T}_{2}=21.29 \mathrm{MJ} / \mathrm{d}$ and $243 \mathrm{~g} / \mathrm{d}(D C P)$ and $255 \mathrm{~g} / \mathrm{d}$ (DCP) for $400 \mathrm{~g} / \mathrm{d}$ targeted BWG, $\mathrm{T}_{3}=23.37 \mathrm{MJ} / \mathrm{d}$ for $600 \mathrm{~g} / \mathrm{d}$ targeted). abcd Mean values in a row with different superscripts differed significantly. ** Significant at $p<0.01, *$ significant at $\mathrm{p}<0.05$ and NS indicates non-significant.

Growth response of crossbred bull calves is depicted in Figure 1. It indicated that dietary group $\mathrm{T}_{1}$ maintained the targeted body weight gain of $200 \mathrm{~g} / \mathrm{d}$ and $\mathrm{T}_{2}$ is near about to maintain targeted $400 \mathrm{~g} / \mathrm{d}$ whereas $T_{3}$ is far behind from targeted body weight gain.

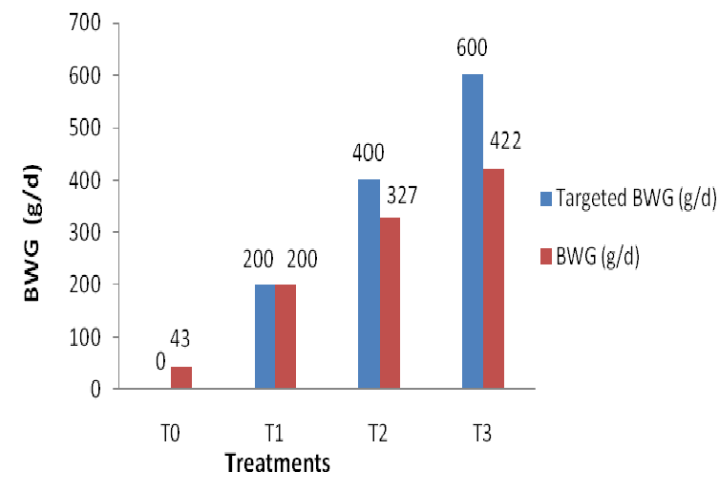

Figure 1. Growth response of crossbred bull calves

Throughout the experimental period resultant average total WHG and BLG of $T_{0}, T_{1}, T_{2}$ and $T_{3}$ groups are shown in Table 4 which indicates that non-significant $\quad(p>0.05)$ difference existed among the groups. This finding is supported by Habib et al. (2018) who stated that increase energy and DCP in diet non-significantly enhances wither height and body length gain in heifers. Also, significant difference $(p<0.05)$ present among the dietary groups and the highest heart girth gain was found in $\mathrm{T}_{3}$ group than others. According to James (2002), about $50 \%$ of the total gain in heart girth occurs during the first 6 months, 25\% from 7-12 months and the remaining $25 \%$ during the last 12 months. It assumes that the skeleton of heart frame also may complete or near to complete its growth within this age limit as because the correlation between height and body weight is 0.97 . Some authors reported a correlation of 0.605-0.97 (Mourad and Anous, 1991) between the heart girth and body weight. Moreover, Khan (2000) also found a statistically non-significant higher heart girth value by using different energy level with animals aged above 2 years. Rahman et al. (1988) conducted an experiment to study the growth performance of baby calves on milk replacers and reported that an average daily gain in heart girth of Local $x$ Sahiwal cross calves was $0.18 \mathrm{~cm}$. 


\section{Feed conversion efficiency}

Feed conversion efficiency of four dietary groups is shown in Table 5 and result implied that there was significant $(p<0.05)$ difference existed among the dietary groups which indicated that different levels of dietary energy and protein had significant effect on the feed conversion efficiency. The present findings agree with Ryan et al. (2007) who reported that there was improvement in feed conversion efficiency due to high digestibility of nutrient. Protein and energetic efficiency also significant differed $(p<0.01)$ among the dietary groups. It observed that $T_{0}$ gave higher values compared to that of other diets. The protein and energetic efficiency were increase with the increased amount of protein and energy level in diet. The present findings are in agreement with Giger-Reverdin (2007) who suggested that increased energy supplements can improve energetic efficiency compared to bull calves fed at maintenance level. Again, Greathouse et al. (1974) reported that higher rate of feed conversion due to rising of protein level in diet.

\section{Calculation of energy and protein requirement}

Figure 2 exhibits the relationship between energy intake and body weight gain of bull calves. There was a very linear increasing relationship of gain with energy intake. Maintenance group took

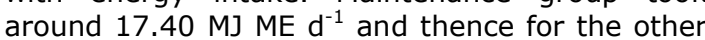
different targeted (200, 400 and 600) daily gain groups took increasing rate of ME up to $23.37 \mathrm{MJ}$ as maximum limit.

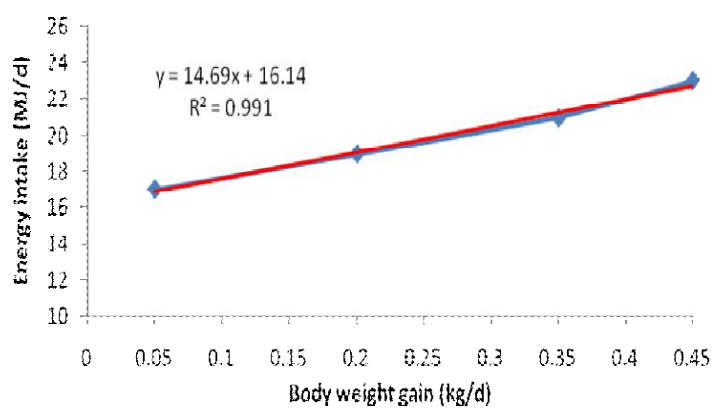

Figure 2. Relationship between body weight change and energy intake of bull calves

Daily energy requirements of $100 \mathrm{~kg}$ growing bull was detected from emitted regression equation, $\left(Y=14.69 X+16.14, \quad R^{2}=0.991\right)$. The intercept (16.14) accounts for required maintenance requirement energy (MJ) for $100 \mathrm{~kg}$ BW bull calves. The $Y$ is the dependent variable (ME) strongly correlated $\left(R^{2}=0.991\right)$ with body weight change.
Again, Figure 3 exhibits the relationship between DCP intake and BWG of bull calves. A strong positive correlation $\left(R^{2}=0.925\right)$ found between digestible crude protein consumed and BWG. The depended variable $Y$ (DCP intake) could be estimated on $X$ daily weight gain $\left(\mathrm{kg} \mathrm{d}^{-1}\right)$ basis. $\mathrm{CP}$ requirement $(\mathrm{g} / \mathrm{d})$ for maintenance and growth could be observed from the imitated simple linear regression equation $\left(\mathrm{Y}=0.555 \mathrm{X}+60.65, \mathrm{R}^{2}=0.925\right)$. There was a very linear increasing relationship of gain with protein intake.

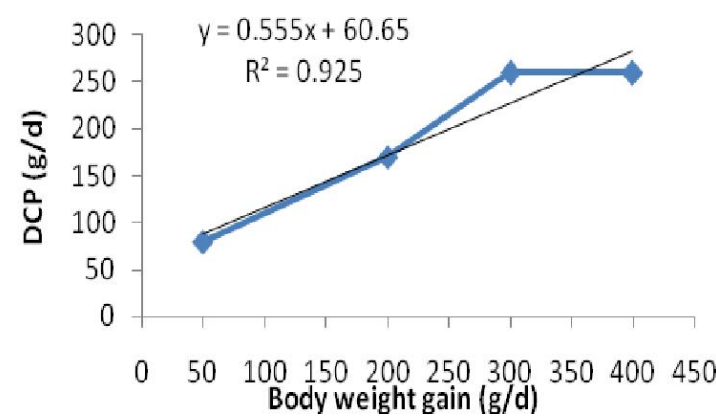

Figure 3. Relationship between body weight change and digestible crude protein intake of bull calves

\section{Conclusion}

Results indicated that $T_{1}$ group achieves targeted body weight gain in crossbred bull calves than other dietary groups. Hence, it may be concluded that supplying of $19.22 \mathrm{MJ} / \mathrm{d}$ metabolizable energy and $188 \mathrm{~g} / \mathrm{d}$ digestible crude protein in diet would give a better performance in fattening of crossbred bull calves. Again, estimated metabolizable energy and digestible crude protein requirement for maintenance was $16.14 \mathrm{MJ} / \mathrm{d}$ and $60.65 \mathrm{~g} / \mathrm{d}$, respectively.

\section{References}

ADAS (1991). Fermentable metabolizable energy content of grass silage, Adas Feed Evaluation Unit, Stratford-Upon-Avon, Technical Bulletin, 91.

AFRC (1993). Energy and protein requirements of ruminants. An advisory manual prepared by the African technical committee on responses to nutrients. Cab International, Wallingford, Uk.

Alam KM, GS Ghosh, A Mondal and MA Akbar (2001). Supplementation and puberty of zebu calves Bangladesh. The Bangladesh veterinarian, 18: 1-8. 


\section{Growth and nutrient requirements of bull calf}

AOAC (2000). Associations of Official Agricultural Chemists, Official Methods of Analysis, seventeenth ed. Washington, DC.

Banglapedia (2014). National Encyclopedia of Bangladesh.

Barua S, MJ Khan, AKFH Bhuiyan, MN Islam and SS Islam (2008). Supplementation of concentrate with different levels of protein on nutrient intake, digestibility and growth of red chittagong heifers. Bangladesh Journal of Animal Science 37(1): 10-16.

Chowdhury SA (1999). Effect Of Graded Levels Of Mustard Oil Cake Supplementation On Intake, Nutrient Digestibility, Microbial N Yield Of Adult Cannulated Native (Bosindicus) Bulls Fed Rice Straw. Asian-Australasian Journal of Animal Science, 12(5): 715-722.

Costa ESLF, FSC Valadares, D Zanetti, PP Rotta, MI Marcondes, LF Prados, MF Paulino and HO Azevedo (2012). Energy and Protein Nutritional Requirements for Nellore Bulls. Revista Brasileira De Zootecnia, Viçosa, 41(6): 1516-1524.

Davis CL and JK Drackley (1998). The development, nutrition, and management of the young calf, Iowa State Univ. Press and Ames, Iowa.

Ferdous S, AKM Masum, MAS Khan and MA Islam (2010). Comparative study on the performance of buffalo calves and cow calves by feeding urea molasses block with straw based diet. Journal of Bangladesh Agricultural University 8(1): 87-90.

Giger-Reverdin (2007). Empirical modeling by meta-analysis of digestive interactions and ch4 production in ruminants. In: Proc. $2^{\text {nd }}$ symp, energy and protein metabolism and nutrition.

Gilbery TC, GP Lardy, SA Soto-Navarro, ML Bauer and JS Caton (2006). Effects of corn condensed distillers solubles supplementation on ruminal fermentation, digestion, and in situ disappearance in steers consuming lowquality hay. Journal of Animal Science 84: $1468-1480$

Greathouse GA, RR Schalles, BE Brent, AD Dayton and EF Smith (1974). Effects of levels and sources of protein on performance and carcass characteristics of steers fed allconcentrate rations. Journal of Animal Science 39: 102-107.

Grigor'ev NG and AP Gaganov (1991). Efficiency of utilization of dietary metabolizable energy by young bull on a diet with varying levels of ME. Journal of Animal Nutrition, 64(1): 3542.
Habib MR, MH Rashid, MA Islam, S Majumder, KM Islam, S Ahmed, MS Alam and E VargasBello-Pérez (2018). Influence of green grassbased diets on growth and reproductive performance in dairy heifers. Tropical animal health and production. https://doi.org/10.1007/s11250-018-1514-x.

James RE (2002). Growth standards and nutrient requirements. Encyclopedia of Dairy Science, Elsevier Science California, USA.pp. 24052411.

Khan MSI (2000). Effect of different dietary energy level on the performance of crossbred dairy heifers. MS Thesis, Submitted to the Department of Dairy Science, Bangladesh Agricultural University, Mymensingh-2202, Bangladesh.

Limea L, M Boval, N Mandonnet, G Garcia, H Archimede and G Alexandre (2009). Growth performance, carcass quality and non carcass components of indigenous caribean goats under varying nutritional densities. Journal of Bull Calves Science, 87: 3770-3781.

MAFF (1984). Energy allowances and feeding systems for ruminants. Ministry of Agriculture, Fisheries and Food, London, Technical Bulletin, 433.

Marston TT, KS Lusby and RP Wettemenn (1995). Effect of post weaning diet on age and weight at puberty and milk production of heifers. Journal of Bull Calves Science, 73: 63-68.

Mohan DVGK and SK Ranjhan (1985). Effect of different levels of energy and protein on nutrient and energy utilization in crossbred heifer calves. Indian Journal of Animal Science 55(6): 450-453.

Mourad M and MR Anous (1991). Effect of herd importation on reproductive and growth traits of alpine goats in Egypt. Indian Veterinary Research Institution 5(2): 33-38.

Mtenga LA and A Madsen (1992). Experiences in protein supplementary feeding of weaned lambs and goat kids in Tanzania: the issue of dietary energy. In: Rey B. Lebbie, S.H.B. And Reynolds, L. (Edition), Small ruminant research and development in Africa, Nairobi, Kenya. Pp. 387-400.

Natthamon T (2012). Effects of metabolizable energy intake on growth performance and nutrient digestibility of Thai native cattle. Iranian Journal of Animal Science, 12(4): 1115.

Paul SS, AB Mandal, GP Mandal, A Kamian and NN Pathak (2004). Deriving nutrient 
requirements of lactating Indian cattle under tropical condition using performance and intake data emanated from feeding trials conducted in different research institutes. Asian-Australasian Journal of Bull Calves Science 17(6): 769-776.

Prakash B, TK Dutta and IA Siddique (2006). Effect of plane of nutrition utilization and performance of Barbari kids. Indian Journal of Bull Calves Nutrition 23(1): 29-33.

Rahman F, MS Rahman, A Wadud and SMI Hussain (1988). Study on the growth performance of baby calves as influenced by milk replacers. Bangladesh Journal of Animal Science 111: 1982-87.

Reddy SKR and MR Reddy (1988).Effect of feeding complete rations on growth and nutrient utilization in crossbred calves. Indian Journal of Bull Calves Nutrition 5(3): 195201.

Ryan SM, JA Unruh, ME Corrigan, JS Drouillard and M Seyfert (2007). Effect of concentrate level on carcass traits of Boer crossbred goat. Small Ruminant Research 73: 67-76.

SAS (2007). SAS User's guide, Statistical Analysis System Institute Inc., Carry, North Carolina, USA.

Satter LD and RE Roffler (1976). Procedure of Research Coordination Meet, Alexandaria, March 15-18, Iaea, Vienna. Pp. 119.

Shahzad MA, NA Tauqir, F Ahmad, M Nisa, M Sarwar and MA Tipu (2010). Effects of feeding different dietary protein and energy levels on the performance of 12-15-monthold buffalo calves. Tropical Bull Calves Health Production 97: 53-58.

Sugimoto M, S Kuzuoka, C Yayota and Y Sato (2004). The effects of grazing and supplemental protein concentrations during the grazing period on subsequent finishing performance and carcass quality in Japanese black cattle steers. Journal of Bull Calves Science 75: 29-35.

Yasmin MF (2006). Effect of supplementing concentrate on intake, digestibility, milk yield and composition of Red Chittagong cows fed urea molasses straw based diet. MS Thesis, Department of Animal Nutrition, Bangladesh Agricultural University, Mymensingh. 